\title{
Three strategic feeding during hatchering of Nile tilapia: effects on organs integrity, parasitism and performance parameters
}

\author{
José Dias-Neto • Gustavo Moraes Ramos Valladão • \\ Pedro Henrique de Oliveira Viadanna $\cdot$ Fabiana Pilarski
}

Received: 3 August 2015/Accepted: 7 January 2016/Published online: 27 January 2016

(C) The Author(s) 2016. This article is published with open access at Springerlink.com

\begin{abstract}
The effect of natural feed, artificial feed, and artificial feed with hormone 17 alpha-methyltestosterone on gill and liver integrity, parasite prevalence and performance parameters during the masculinization phase of Nile tilapia Oreochromis niloticus were evaluated. The experiment consisted of the three feeding strategies in triplicate. Water parameters, histopathological, parasitological and performance analyses were performed on day 7, 14, 28 and 60. Both artificial feeds (with and without hormone) were harmful to the hepatic and branchial integrity. The most significant change in liver was lipid degeneration, while in gills a significantly higher lamellar edema was observed when compared to fish that received the natural feed. Fish fed with the artificial diet (with and without hormone) showed a high prevalence $(p<0.05)$ of trichodinids and Cryptobia, while fish that received natural feed showed no parasites after 28 days of study. Fries that received diet with hormone experienced damage to their health, which decreased the survival of this group. The anabolic effect of this molecule, however, improved significantly $(p<0.05)$ their productive performance. Despite the absence of deleterious effects to fish health, the use of natural feed has a high risk of introducing predators. Introduction of odonate larvae drastically affected the survival of this group at the end of the study. All feeding strategies investigated have positive and negative effects that were discussed in the present study.
\end{abstract}

Keywords 17 Alpha-methyltestosterone $\cdot$ Gill $\cdot$ Histopathology $\cdot$ Larvae $\cdot$ Liver $\cdot$ Masculinization

\section{Introduction}

Nile tilapia Oreochromis niloticus is an omnivorous species with herbivorous tendency, however, fish farmers use commercial diets with high protein content, including from animal source as viscera and blood meal (Furuya 2010). Diets rich in proteins used for fish production present a high cost and increase the load of nitrogenous compounds in water (Silva et al. 1991; Moreira et al. 2008). An excess of nitrogenous compounds in an aquatic production system causes a reduction of dissolved oxygen, sudden fluctuations of $\mathrm{pH}$, and a proliferation of pathogenic agents. Furthermore, high protein diets can be harmful to the animal metabolism

\footnotetext{
J. Dias-Neto

PreVet Sanidade Aquícola, Jaboticabal, São Paulo, Brazil

G. M. R. Valladão $(\bowtie) \cdot$ P. H. de Oliveira Viadanna $\cdot$ F. Pilarski

Aquaculture Center, Universidade Estadual Paulista, Rod. Paulo Donato Castellane, s/n, Jaboticabal,

São Paulo CEP: 14.884-900, Brazil

e-mail: gmrvalladao@gmail.com
} 
(Elangovan and Shim 1997; Geurden et al. 1998; Abdel-Tawwab et al. 2010). A high protein intake provokes hepatic and renal alterations, which culminate in organic disequilibrium. Thus, researchers have adopted the use of histopathology to evaluate the effects of different substances administered to fish for ingestion (Schwaiger et al. 1997), including nutritional factors (Mahmoud et al. 2014).

In addition to the use of artificial feed, the production of tilapia is characterized by obtaining a monosex stock through the use of the hormone 17 alpha-methyltestosterone. The hormone is incorporated in feed and administered during hatchery phase. 17 alpha-methyltestosterone has the advantages of producing a stock of more than $90 \%$ males and acts as an anabolic agent (Chakraborty et al. 2011), which improves the productive performance of the larvae. However, the use of this hormone is criticized due to the negative effects as residues in water and sediment (Ong et al. 2012), and damages to the organs that metabolize molecules (Hasheesh et al. 2011). In the production of tilapia, negative effects of hormone become aggravated due to the use of high levels of protein and lipids in the diet.

The natural diet of most cultured aquatic organisms consists of a wide diversity of phytoplankton (diatoms, flagellates, etc.) and zooplankton (copepods, cladocerans, decapod larvae, rotifers, ciliates, etc.). The abundance and maximal diversity of organisms of different sizes and nutritional composition provide maximal chances for meeting all the requirements of the predator larvae (Lavens and Sorgeloos 1996). As the production of live organisms can be expensive, many species of fish larvae (e.g. Nile tilapia) are fed directly with artificial feed (high in protein and limited in ingredients). In order to reduce costs, some fish farmers have fed the fish with natural microorganisms collected directly from earth ponds. This strategy was compared to the use of artificial feed (with and without hormone).

Occurrence of parasitic infestations is another problem frequently encountered in aquaculture, especially during hatchery and nursery phases (Woo and Bruno 2011). The dispersion of these pathogens occurs due to the intensification of production (Garcia et al. 2013), which is characterized by a high density of fish and a higher input of artificial feed. Both high density and a greater input of artificial feed are responsible for the increase of organic matter in aquatic environment. There are direct relationships between the parasite incidence and the nutrient content (in particular organic matters) in fish and shrimp farming (Aghuzbeni et al. 2015). Considering that the use of artificial feed and subsequent accumulation of organic matter can facilitate the development of ectoparasites, parasitological analysis was performed for a comparative study between the different diets in initial phase of Nile tilapia production.

In this study, effects of artificial diet (with and without the hormone) and natural feed on performance, integrity of liver and gill, and parasitism of Nile tilapia were evaluated.

\section{Materials and methods}

Study design

This study was conducted in fish farm (larviculture) of Nile tilapia. Larvae were collected from reproduction ponds through the ichthyoplankton fine mesh nets, where the reproducers were stocked in the proportion of 150 females to 50 males per pond.

Table 1 Composition of the milled artificial feed (for larvae) and extruded (for juvenile fish)

\begin{tabular}{llc}
\hline Guarantee levels/kg of feed & Larvae & Juvenile \\
\hline Humidity (max) & $0.75 \mathrm{~g}$ & $0.67 \mathrm{~g}$ \\
Protein (min) & $485 \mathrm{~g}$ & $440 \mathrm{~g}$ \\
Ether extract (min) & $66 \mathrm{~g}$ & $80 \mathrm{~g}$ \\
Mineral material (max) & $158 \mathrm{~g}$ & $121 \mathrm{~g}$ \\
Fibrous material (max) & $16 \mathrm{~g}$ & $15 \mathrm{~g}$ \\
Phosphorous (min) & $15 \mathrm{~g}$ & $15 \mathrm{~g}$ \\
Vitamin C (min) & $800 \mathrm{mg}$ & $800 \mathrm{mg}$ \\
MOS (min) & $60 \mathrm{mg}$ & $60 \mathrm{mg}$ \\
\hline
\end{tabular}

MOS manano-oligosacharides 
Fish larvae were classified and distributed in 9 circular, polyethylene tanks $(750$ l) with a continuous flow and a rate of total water renovation in $24 \mathrm{~h}$. Each tank received 1000 larvae, which resulted in an initial biomass of approximately $18 \mathrm{~g}$ in each experimental unit.

Experimental design

The experiment consisted of three different larval feeding strategies, with each strategy being conducted in triplicate. A group of fish received an artificial feed designed for this species, another group received the artificial diet that contained the hormone 17 alpha-methyltestosterone, and the third group received the natural feed that consisted of phytoplankton and zooplankton.

The composition of artificial diet and feed management are shown in Tables 1 and 2, respectively. The feed that contained the masculinizing hormone was prepared by adding $60 \mathrm{mg} / \mathrm{kg}$ of 17 alpha-methyltestosterone diluted in ethyl alcohol $\left(92.8^{\circ}\right)$ for each kilogram of feed. The masculinization step was carried out during the initial 40 days of feeding to simulate the most common strategy used in fish farms. After this period, all of the fish were fed the commercial feed and the experiment was concluded at 120 days of feeding to perform the final biometrics for the productive performance data.

Natural feed used for the third group of fish was collected daily from an earthen pond by using a phytoplankton net $(25 \mu \mathrm{m})$. The concentrate (approximately $200 \mathrm{~mL}$ ) was diluted in $5 \mathrm{~L}$. This diet was provided five times each day (during 40 days).

During the study, the levels of the dissolved oxygen (DO), temperature $\left(T^{\circ} \mathrm{C}\right), \mathrm{pH}$ and ammonium $\left(\mathrm{NH}_{4}\right)$ of each tank were measured daily with a multiparameter probe (YSI Professional Plus ${ }^{\circledR}$ ). The data were described as mean \pm standard deviation.

Histopathological analysis

Gills and liver have been evaluated for description and comparison of histopathological lesions. Nine fish have been collected from each treatment per sampling (days 0, 7, 14, 28 and 60). The fries have been fixed in $10 \%$ formalin, dehydrated in increasing solutions of alcohol, diaphanized in xylene and paraffin-embedded $\left(\right.$ Merck $\left.^{\circledR}\right)$, according to standard protocol. The slides were stained with hematoxylin and eosin (H\&E), and the histopathological lesions were analyzed by pairs of pathologists for elaboration of descriptions, which were expressed in a qualitative manner and grouped in similar sets.

Photomicrographs were made with a light microscope $\left(\right.$ Nikon E200 $\left.{ }^{\circledR}\right)$ and were used to analyze the hepatic and branchial structures. For hepatic structures, analyses consisted of measuring the size of the hepatocyte vacuole, area of the hepatocyte nucleus, and size of hepatocyte with and without degeneration (Fig. 1), according to Raskovic et al. (2011) and Strussmann and Takashima (1990). For branchial structures, analyses consisted of measuring the lamellar edema (space between the lamellar epithelium and the pillar cells), the size of interlamellar space and diameter of mucous cell (Fig. 2), according to Stevens (1992). All structures were photographed in three random areas of each glass slide and measured using the software Image Processing and Analysis-Image $\mathbf{J}^{\circledR}$.

Table 2 Quantity and frequency of feeding of the groups that received artificial diet (with and without hormone)

\begin{tabular}{llll}
\hline Day & Feed $(\mathrm{g}) /$ tank & Daily frequency & Feed $(\mathrm{g}) /$ day/Tank \\
\hline 0 & 0.2 & 7 & 1.4 \\
7 & 0.3 & 6 & 1.8 \\
14 & 0.6 & 5 & 3.0 \\
28 & 1.0 & 5 & 5.0 \\
37 & 2.0 & 5 & 10 \\
53 & 4.0 & 5 & 20 \\
\hline
\end{tabular}




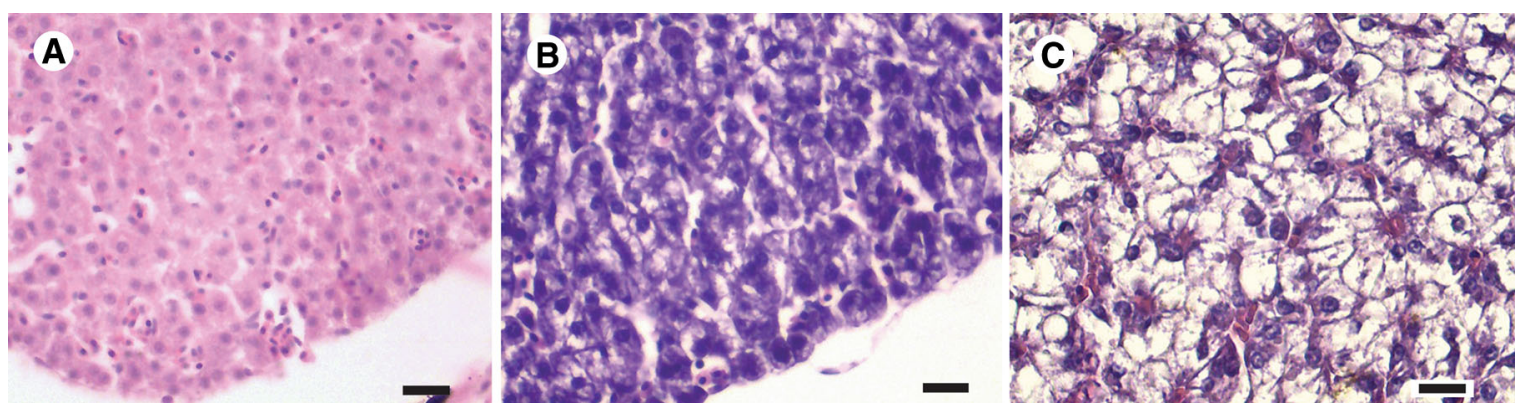

Fig. 1 Liver histology of Nile tilapia. Healthy liver tissue (a); hydropic degeneration (b); lipid degeneration (c). Scale $10 \mu \mathrm{m}$

Parasitological analysis

Parasitological analyses were carried out at 7,14 and 28 days from the beginning of feeding; 9 fries were sampled from each treatment. In the first two samplings (days 7 and 14) larvae were compressed between a slide and a cover slip due to their size. For the sampling on day 28 , the mucus of the integument and biopsy of the gill arches were carried out separately, which were viewed by light microscopy used for research of ectoparasites.

Parasites were identified by genus or group and the data were arranged in prevalence (\%) by the formula: number of infected fish with parasites $\div$ number of fish analyzed $\times 100$.

Performance parameters

For the analysis of productive performance, an initial and a final sampling with all fish in the experiment was carried out. Fries were counted, measured (total length), and weighed. All performance parameters were collected at day 120 following the handling of fish farm.

The results were organized as survival $(S)$, weight gain (GP), and feed conversion (CA), which were conducted by the formulas: Weight gain $(\mathrm{GP})=$ Final weight - Initial weight; Feed conversion $(\mathrm{CA})=($ Quantity of food consumed throughout the entire period $) \div$ GP; Survival $(S)=$ final number of fish $\div$ initial number of fish $\times 100$.

Statistical analysis

One-way analysis of variance (ANOVA), Tukey test, and the Levenne test were used for homoscedasticity (parasitological and morphometric data of the liver and gills). The Mann-Whitney test, which was one tailed with a confidence interval of $95 \%$, and the Kruskal-Wallis ANOVA were used for non-parametric data. The statistical analyses were conducted using the programs STATISTIC $10^{\circledR}$ STATSOFT 1984-2011 and GraphPad Prism $5^{\circledR}$.

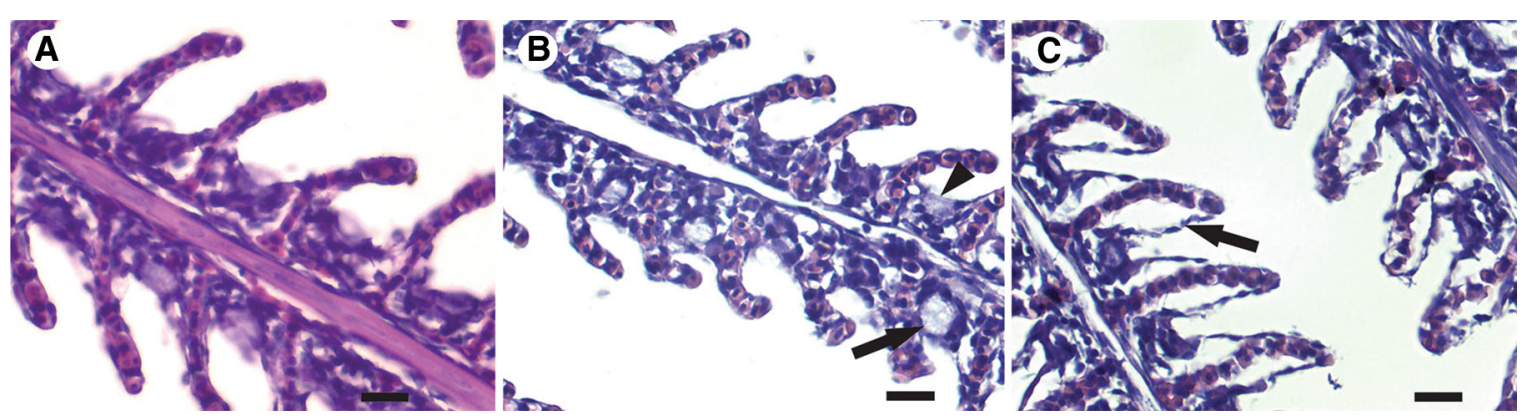

Fig. 2 Gill histology of Nile tilapia. Healthy brachial tissue (a); mucous cells (arrow) and chloride cells (arrow head) (b); lamellar edema in arrow head (c). Scale $10 \mu \mathrm{m}$ 


\section{Results}

\section{Water parameter}

The concentration of ammonium was significantly different according to the type of fish feed. The tanks that received the natural feed displayed a lower $(p<0.05)$ concentration of ammonium when compared to tanks that received artificial feed (with and without hormone) (Table 3).

Histopathological analysis

All samples of day 7 and 14 showed hydropic degeneration of the liver, apart the treatment made. On day 28 , only the larvae that received the hormone had the hydropic degeneration.

At the end of the experiment, the group that received the natural feed displayed a higher number of fish with the typical appearance of normal tissue $(20 \%$ of the fish had no-lesion of the liver and $33 \%$ had no lesion of the gills). In contrast, the fish fed with the artificial diet (with and without the hormone) showed a greater number and severity of lesions, such as lipid degeneration. Edema of branchial lamellae was also less pronounced in the fish fed with natural feed at the end of experiment (Table 4).

The group of fish that received natural feed showed a significantly lower area of hepatocyte nucleus $(p<0.05)$ than those of larvae fed with artificial diet at day 14 (Table 5). The size of hepatocytes without lipid degeneration was significantly lower $(p<0.05)$ in larvae receiving the natural feed when compared to group receiving artificial diet (Table 5). In addition, on days 14 and 60, the size of hepatocytes (with and without degeneration) was also significantly lower $(p<0.05)$ for fries fed with natural feed (Table 5).

Before the start of the experiment, every lamellar edema found in the gills of fish was measured, and those that received natural feed had a higher branchial edema $(p<0.05)$. Starting at day 14 of feeding, however, this group presented a smaller lamellar edema during and after the experiment $(p<0.05)$ (Table 6). Furthermore, the interlamellar space was significantly higher in this group at day 7 of the treatment when compared to those fed with the artificial diet. The areas of the mucus cells were significantly lower in the fish fed with the artificial feed after 28 days of feeding (Table 6).

\section{Parasitism}

When considering the total parasitism observed from integument and gill, 8 different parasites were found throughout the study. Fish that received natural feed, however, was free of any parasitic agents starting at day 28 of feeding (Table 7). In this same moment, groups that received the artificial feed were parasitized by

Table 3 Changes in water parameters related to different feed strategies during 60 days

\begin{tabular}{llllll}
\hline Parameter & Feed & Day 7 & Day 14 & Day 28 & Day 60 \\
\hline Dissolved oxygen $(\mathrm{mg} / \mathrm{L})$ & AF & $7.13 \pm 0.082$ & $7.14 \pm 0.181$ & $6.60 \pm 0.208$ & $6.18 \pm 0.403$ \\
& AF $+\mathrm{H}$ & $7.27 \pm 0.150$ & $7.16 \pm 0.0115$ & $6.62 \pm 0.07$ & $6.53 \pm 0.175$ \\
& $\mathrm{NF}$ & $7.30 \pm 0.173$ & $7.21 \pm 0.0058$ & $6.73 \pm 0.04$ & $6.66 \pm 0.177$ \\
$\mathrm{pH}$ & $\mathrm{AF}$ & $6.92 \pm 0.0058$ & $6.82 \pm 0.0058$ & $6.73 \pm 0.01$ & $6.66 \pm 0.0321$ \\
& $\mathrm{AF}+\mathrm{H}$ & $6.92 \pm 0.0058$ & $6.82 \pm 0$ & $6.77 \pm 0.02$ & $6.66 \pm 0.0231$ \\
& $\mathrm{NF}$ & $6.93 \pm 0.0071$ & $6.82 \pm 0.0058$ & $6.77 \pm 0.02$ & $6.59 \pm 0.0611$ \\
Temperature $\left(\mathrm{T}{ }^{\circ} \mathrm{C}\right)$ & AF & $24.40 \pm 0$ & $25.23 \pm 0.058$ & $23.93 \pm 0.058$ & $20.40 \pm 0.1$ \\
& AF $+\mathrm{H}$ & $24.40 \pm 0$ & $25.23 \pm 0.058$ & $23.93 \pm 0.058$ & $20.63 \pm 0.058$ \\
& $\mathrm{NF}$ & $24.45 \pm 0.071$ & $25.13 \pm 0.058$ & $23.90 \pm 0$ & $20.57 \pm 0.379$ \\
Ammonium $(\mathrm{mg} / \mathrm{L})$ & $\mathrm{AF}$ & $0.37^{\mathrm{a}} \pm 0.115$ & $0.20^{\mathrm{a}} \pm 0$ & $0.13^{\mathrm{a}} \pm 0.0577$ & $1.47^{\mathrm{a}} \pm 0.153$ \\
& AF $+\mathrm{H}$ & $0.20^{\mathrm{a}} \pm 0$ & $0.20^{\mathrm{a}} \pm 0$ & $0.10^{\mathrm{a}} \pm 0$ & $1.30^{\mathrm{a}} \pm 0$ \\
& $\mathrm{NF}$ & $0.10^{\mathrm{b}} \pm 0$ & $0.10^{\mathrm{b}} \pm 0$ & $0.000001^{\mathrm{b}} \pm 0$ & $0.90^{\mathrm{b}} \pm 0.173$ \\
\hline
\end{tabular}

$A F$ artificial feed, $A F+H$ artificial feed with the hormone 17 alpha-methyltestosterone, $N F$ natural feed

Different letters signify difference between the groups $(p<0.05)$ 
Table 4 Percentage of analysed fish (Nile tilapia) with gill and hepatic histopathological alterations (descriptive analyses)

\begin{tabular}{clll}
\hline & AF & AF + H & NF \\
\hline $\begin{array}{c}\text { Day } 0 \\
\text { Liver }\end{array}$ & $100 \% \mathrm{LD}$ & $100 \% \mathrm{LD}$ & $100 \% \mathrm{LD}$ \\
Gill & $33 \% \mathrm{LE}$ & $100 \% \mathrm{LE}$ & $100 \% \mathrm{LE}$ \\
Day 7 & & $33 \% \mathrm{HD}$ & $33 \% \mathrm{LD}, 67 \% \mathrm{HD}$ \\
Liver & $100 \% \mathrm{HD}$ & $100 \% \mathrm{LE}$ & $100 \% \mathrm{LE}$ \\
Gill & $100 \% \mathrm{LE}$ & & $100 \% \mathrm{HD}$ \\
Day 14 & $33 \% \mathrm{LD}, 67 \% \mathrm{HD}$ & $100 \% \mathrm{LE}$ & $100 \% \mathrm{NS}$ \\
Liver & $100 \% \mathrm{LE}$ & & $100 \% \mathrm{LD}$ \\
Gill & $100 \% \mathrm{LD}$ & $57 \% \mathrm{HD}, 43 \% \mathrm{LD}$ & $100 \% \mathrm{LE}$ \\
Day 28 & $100 \% \mathrm{LE}$ & $100 \% \mathrm{LE}$ & \\
Liver & & & $20 \% \mathrm{NS}, 60 \% \mathrm{HD}, 20 \% \mathrm{LD}$ \\
Gill & $100 \% \mathrm{LD}$ & $33 \% \mathrm{HD}, 67 \% \mathrm{LD}$ & $33 \% \mathrm{NS}, 67 \% \mathrm{LE}$ \\
Day 60 & $100 \% \mathrm{LE}$ & $12.5 \% \mathrm{NS}, 87.5 \% \mathrm{LE}$ & \\
Liver & & & \\
Gill & & &
\end{tabular}

$A F$ artificial feed, $A F+H$ artificial feed with the hormone 17 alpha-methyltestosterone, $N F$ natural feed, $L D$ lipid degeneration, $H D$ hydropic degeneration, $L E$ lamelar edema, $N S$ normal structure

trichodinids and parasites of the genera Cryptobia, Ichthyobodo, Piscinoodinium and Chilodonella (Table 7). Special emphasis is given to the prevalence of trichodinids and Cryptobia, which were significantly higher in groups fed with artificial diet (with and without hormone) $(p<0.05)$.

In relation to exclusive analysis of the gills (data obtained only on day 28), trichodinids, Cryptobia and Chilodonella were diagnosed. Similar to the results described above, gill parasites were not found on the fries that received natural feed and the prevalence of trichodinids and Cryptobia was significantly higher $(p<0.05)$ in groups that received artificial diets (with and without hormone) (Table 8).

Performance parameters

The survival was higher in group that received artificial diet without addition of hormone. Survival was not measured in group fed with phytoplankton and zooplankton due to a mortality that occurred at the end of experiment from an infestation of odonate larvae in the tanks. The larvae of this insect has an aquatic larval stage, which is believed to have been carried from collection of natural feed to experimental tanks, resulting in mortality of fish of this group.

Weight gain and final length were higher in the group that received diet containing hormone. Because of these results, the feed conversion was lower in fish fed with artificial diet containing hormone 17 alphamethyltestosterone (Table 9).

\section{Discussion}

In addition to environmental stress, Popma and Lovshin (1994) suggested that physiological stress caused by use of steroid hormones is one of the main contributors to the high mortality in initial production cycle. Even so, the most common nutritional strategy during the feeding of the tilapia larvae is the addition of the hormone 17 alpha-methyltestosterone, which aims to produce a monosex stock. This production strategy is the most viable to the producer when compared to the techniques used to produce supermales or hybrids. However, hormone incorporation is inconvenient and laborious in addition to creates waste to the environment and reducing the survival rate of fish larvae (Valentim-Zabott et al. 2008).

Quality and quantity of ingredients in diet can cause alterations in the integrity of fish organs. For example, liver is responsible for producing the precursor protein of hormones, coagulation cascade, and complement, in 


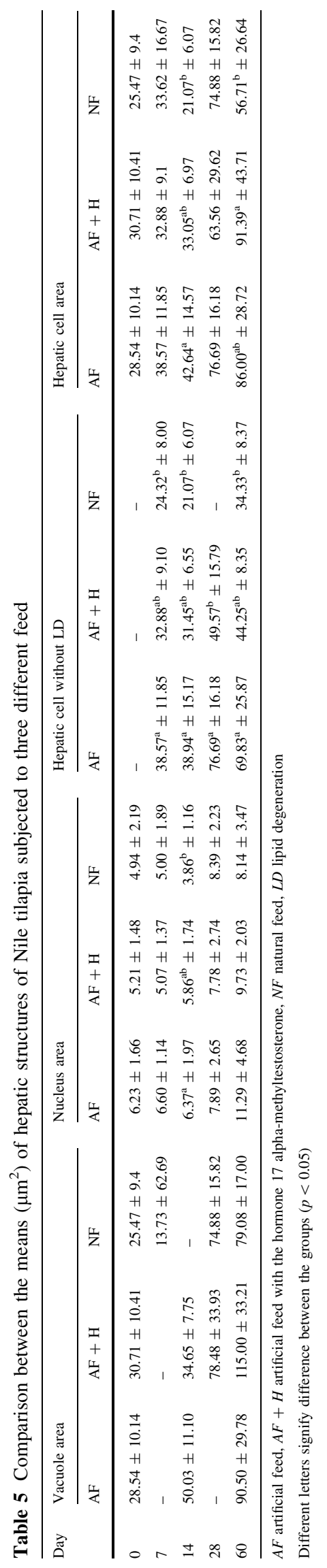




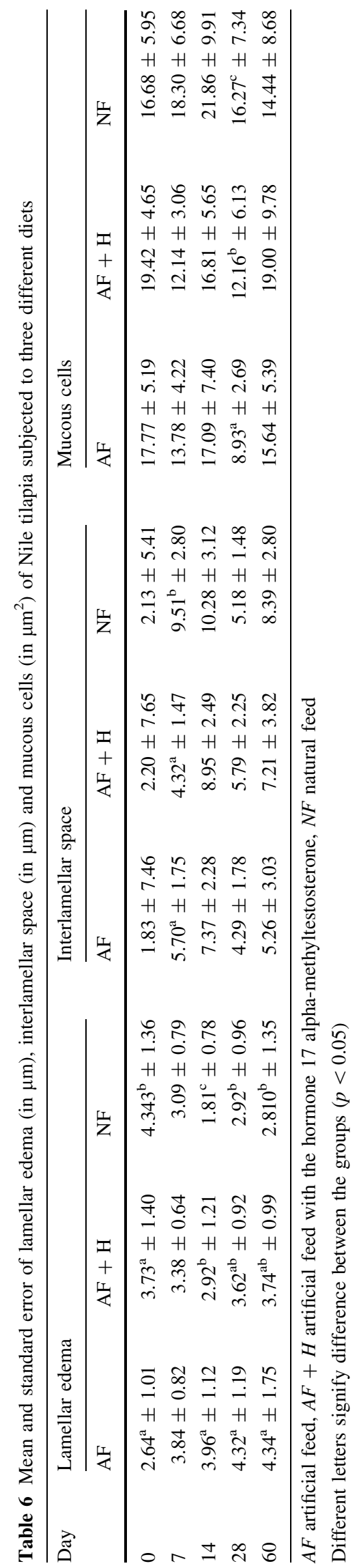




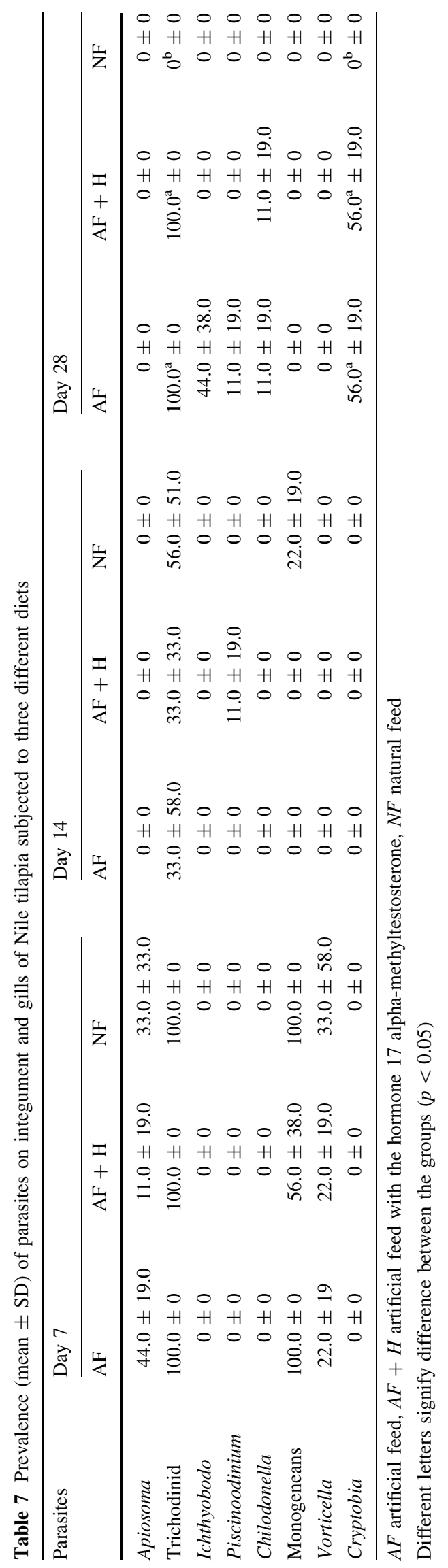


Table 8 Prevalence (\%) of parasites on gills of Nile tilapia subjected to three different diets

\begin{tabular}{lcrr}
\hline Parasites & \multicolumn{2}{l}{ Day 28} & \\
\cline { 2 - 4 } & AF & AF + H & NF \\
\hline Trichodinid & $56.0^{\mathrm{a}} \pm 19.0$ & $0^{\mathrm{b}} \pm 0$ & $0^{\mathrm{b}} \pm 0$ \\
Cryptobia & $56.0^{\mathrm{a}} \pm 19.0$ & $56.0^{\mathrm{a}} \pm 19.0$ & $0^{\mathrm{b}} \pm 0$ \\
Chilodonella & $0 \pm 0$ & $11.0 \pm 19.0$ & $0 \pm 0$ \\
\hline
\end{tabular}

$A F$ artificial feed, $A F+H$ artificial feed with the hormone 17 alpha-methyltestosterone, $N F$ natural feed

Different letters signify difference between the groups $(p<0.05)$

Table 9 Survival, weight gain, length and feed conversion of Nile tilapia subjected to three different diets

\begin{tabular}{llll}
\hline & AF & AF $+\mathrm{H}$ & $\mathrm{NF}$ \\
\hline Survival (\%) & 49.30 & 40.02 & - \\
Weight gain (grams) & $8.35^{\mathrm{a}} \pm 3.42$ & $9.27^{\mathrm{b}} \pm 4.56$ & - \\
Length (cm) & $7.37^{\mathrm{a}} \pm 1.22$ & $7.69^{\mathrm{b}} \pm 1.48$ & - \\
Feed conversion & $4.6: 1$ & $2.3: 1$ & -
\end{tabular}

$A F$ artificial feed, $A F+H$ artificial feed with the hormone 17 alpha-methyltestosterone, $N F$ natural feed

Different letters signify difference between the groups $(p<0.05)$

addition to producing the globulins that comprise antibodies and lytic enzyme of immune system, and also being the main storage location for vitamins (Kaneko et al. 2008). Thus, a disorder in this organ can lead to irreparable consequences and compromise the survival of organisms, which was observed in this study. Similarly, Gayão et al. (2013) found greater hepatic alterations in fish that received steroid hormone in a diet with a high level of protein. The most observed alterations were increased cell volume, disarrangement of cordonal structure, and an increased number of vesicles in the hepatocytes (Gayão et al. 2013). Also, Hasheesh et al. (2011) described diffuse vacuolar degeneration followed by severe vacuolation of the hepatocytes in fish that consumed a diet with $60 \mathrm{mg} / \mathrm{kg}$ of 17 alpha-methyltestosterone. The increase of hepatocyte size observed in fish that received artificial diet with hormone is connected to molecular metabolism in the liver. Thus, the hepatocytes remained small within the fries that received the natural feed and were not exposed to any molecule or drug.

The water parameter indicates that the tanks which were fed with artificial feed (with and without hormone) had higher amount of ammonium. Accumulation of nitrogenous compounds (Rodrigues et al. 2012), chemical substances present in water (Roberts 2012) and ectoparasites (Valladão et al. 2013) can cause severe alterations in gill structure, compromising the function of its filaments. Lamellar edema is the most common lesion in fish and may progress to necrosis of lamellar epithelium, causing respiratory and osmoregulatory distress, which then leads to a compromise in the health, development and survival of fish (Yang and Albright 1992). Natural feed was more beneficial to health of the gills, which may have correlated to both a low intake of nitrogen compounds in water and a lower intensity of important gill parasites, such as the genera Trichodina, Cryptobia, and Chilodonella. An improvement in the state of this organ can increase the health and survival of fish. The use of natural feed captured from external tanks and without predator control as performed in several fish farms, however, is discouraged since significant losses can occur of up to an entire stock. On the other hand, this can be highly recommended if the natural feed is produced in artificial and controlled conditions to ensure safety.

Trichodinids are one of the most common and important ectoparasites of tilapia worldwide. They are also responsible for acute mortalities of fish larvae (Valladão et al. 2014). The use of artificial feed (with or without the hormone) favoring the proliferation of these important pathogens, while natural feed can be an interesting strategy from the sanitary point of view for fish larviculture.

Productive performance (weight gain and growth) was superior in larvae that received diet with hormone, which can be explained by the use of steroid in the masculinization of these larvae. By being a synthetic anabolic agent, 17 alpha-methyltestosterone has the capacity to increase protein synthesis and increase the 
muscle mass of the fish, which was also observed in other species of fish such as Labeo rohita (Pandey et al. 2014). The use of the hormone, however, can decrease the survival of the fish.

All strategies studied are currently used in fish production. It is difficult to conclude which feeding strategy is the ideal, since each strategy shows its own unique benefits and problems. From production perspective, the use of hormone 17 alpha-methyltestosterone is recommend because it promotes the production of a monosex stock and a greater growth of fish. From health and environmental perspective, artificial diet without hormone and natural diet are most recommended because the steroid can damage organs, impair the healthy development, survival and pollute the environment. Still, the use of natural feed shows a lower prevalence of ectoparasites in relation to fries fed with the artificial diets, but shows a high risk of biological contamination such as the presence of odonate larvae. Therefore, the cultivation of the natural feed should be carried out in a controlled environment to be safe. The use of artificial diet without hormone does not show the negative effects of the steroid, thus the fish is healthier and the environment is not affected. In this case, however, the producer must seek another strategy for producing a monosex stock.

Open Access This article is distributed under the terms of the Creative Commons Attribution 4.0 International License (http:// creativecommons.org/licenses/by/4.0/), which permits unrestricted use, distribution, and reproduction in any medium, provided you give appropriate credit to the original author(s) and the source, provide a link to the Creative Commons license, and indicate if changes were made.

\section{References}

Abdel-Tawwab M, Ahmad MH, Khattab YAE, Shalaby AME (2010) Effect of dietary protein level, initial body weight, and their interaction on the growth, feed utilization, and physiological alterations of Nile tilapia, Oreochromis niloticus (L.). Aquaculture 298(3):267-274

Aghuzbeni SHH, Hossein S, Hajirezaee S, Khara H (2015) Polyculture of western white shrimp, Litopenaeus vannamei Boone, 1931 with Grey mullet, Mugil cephalus Linnaeus, 1758 controls external parasites of western white shrimp. Aquac Res. doi:10.1111/are.12751

Chakraborty SB, Banerjee S, Chatterjee S (2011) Increased androgen receptor expression in muscle tissue contributing to growth increase in androgen-treated Nile tilapia. Aquac Int 19(6):1119-1137

Elangovan A, Shim KF (1997) Growth response of juvenile Barbodes altus fed isocaloric diets with variable protein levels. Aquaculture 158(3-4):321-329

Furuya WM (2010) Tabelas brasileiras para a nutrição de tilápias. GFM, Toledo, p 100

Garcia F, Romera DM, Gozi KS, Onaka EM, Fonseca FS, Schalch SHC, Candeira PG, Guerra LOM, Carmo FJ, Carneiro DJ, Martins MIEG, Portella MC (2013) Stocking density of Nile tilapia in cages placed in a hydroelectric reservoir. Aquaculture 410:51-56

Gayão ALBDA, Buzollo H, Fávero GC, Silva-Júnior AA, Portella MC, Cruz C, Carneiro DJ (2013) Hepatic histology and cage production of Nile tilapia hormonally masculinized or nonmasculininized. Pesqui Agropecu Bras 48(8):991-997

Geurden I, Reyes OS, Bergot P, Coutteau P, Sorgeloos P (1998) Incorporation of fatty acids from dietary neutral lipid in eye, brain and muscle of postlarval turbot fed diets with different types of phosphatidylcholine. Fish Physiol Biochem 19:365-375

Hasheesh WS, Marie MAS, Abbas HH, Eshak MG, Zahran EA (2011) An evaluation of the effect of 17 $\alpha$-methyltestosterone hormone on some biochemical, molecular and histological changes in the liver of Nile Tilapia, Oreochromis niloticus. Life Sci J 8(3):343-358

Kaneko JJ, Harvey JW, Bruss ML (2008) Clinical biochemistry of domestic animals. Academic Press, San Diego, p 932

Lavens P, Sorgeloos P (1996) Manual on the production and use of live food for aquaculture (No. 361). Food and Agriculture Organization (FAO). Avaiable in http://www.fao.org/docrep/003/w3732e/w3732e02.htm

Mahmoud MM, Kilany OE, Dessouki AA (2014) Effects of fish meal replacement with soybean meal and use of exogenous enzymes in diets of Nile Tilapia (Oreochromis niloticus) on growth, feed utilization, histopathological changes and blood parameters. Life Sci J 11(2):6-18

Moreira IS, Peres H, Couto A, Enes P, Oliva-Teles A (2008) Temperature and dietary carbohydrate level effects on performance and metabolic utilization of diets in European sea bass (Dicentrarchus labrax) juveniles. Aquaculture 274(1):153-160

Ong SK, Chotisukarn P, Limpiyakorn T (2012) Sorption of 17 $\alpha$-methyltestosterone onto soils and sediment. Water Air Soil Pollut 223(7):3869-3875

Pandey AK, Sarkar M, Kanungo G, Mahapatra CT, Arvindakshan PK (2014) Effects of varying dietary protein and 17 $\alpha-$ Methyltestoterone on growth and survival of fry of Labeo rohita (Hamilton-Buchanan). J Exp Zool 17(2):687-691

Popma TJ, Lovshin LL (1994) Worldwide prospects for commercial production of tilapia. Auburn University, Auburn, p 42

Raskovic BS, Stankovic MB, Markovic ZZ, Poleksic VD (2011) Histological methods in the assessment of different feed effects on liver and intestine of fish. J Agric Sci 56(1):87-100

Roberts RJ (2012) Fish pathology. Wiley-Blackwell, Iowa, p 581

Rodrigues RV, Romano LA, Schwarz MH, Delbos B, Sampaio LA (2012) Acute tolerance and histopathological effects of ammonia on juvenile maroon clownfish Premnas biaculeatus (Block 1790). Aquac Res 45(7):1133-1339 
Schwaiger J, Wanke R, Adam S, Pawert M, Honnen W, Triebskorn R (1997) The use of histopathological indicators to evaluate contaminant-related stress in fish. J Aquat Ecosyst Stress Recovery 6(1):75-86

Silva SS, Guanasekera RM, Shim KF (1991) Interactions of varying dietary protein and lipid levels in young red tilapia: evidence of protein sparing. Aquaculture 95(3-4):305-318

Stevens ED (1992) Gill morphometry of the red drum, Sciaenops ocellatus. Fish Physiol Biochem 10(2):169-176

Strussmann CA, Takashima F (1990) Hepatocyte nuclear size and nutritional condition of larval pejerrey, Odontesthes bonariensis (Cuvier et Valenciennes). J Fish Biol 36:59-65

Valentim-Zabott M, Vargas L, Ribeiro RPR, Piau R, Torres MBA, Rönnau M, Souza JC (2008) Effects of a homeopathic complex in Nile tilapia (Oreochromis niloticus) on performance, sexual proportion and histology. Homeopathy 97(4):190-195

Valladão GMR, Pádua SB, Gallani SU, Menezes-Filho RN, Dias-Neto J, Martins ML, Pilarski F (2013) Paratrichodina africana (Ciliophora): a pathogenic gill parasite in farmed Nile tilapia. Vet Parasitol 197(3):705-710

Valladão GMR, Gallani SU, Pádua SB, Martins ML, Pilarski F (2014) Trichodina heterodentata (Ciliophora) infestation on Prochilodus lineatus larvae: a host-parasite relationship study. Parasitology 141(05):662-669

Woo PT, Bruno DW (2011) Fish diseases and disorders. CABI, Wallingford, p 944

Yang CZ, Albright LJ (1992) Effects of the harmful diatom Chaetoceros concavicornison respiration of rainbow trout Oncorhynchus mykiss. Dis Aquat Organ 14(2):105-114 